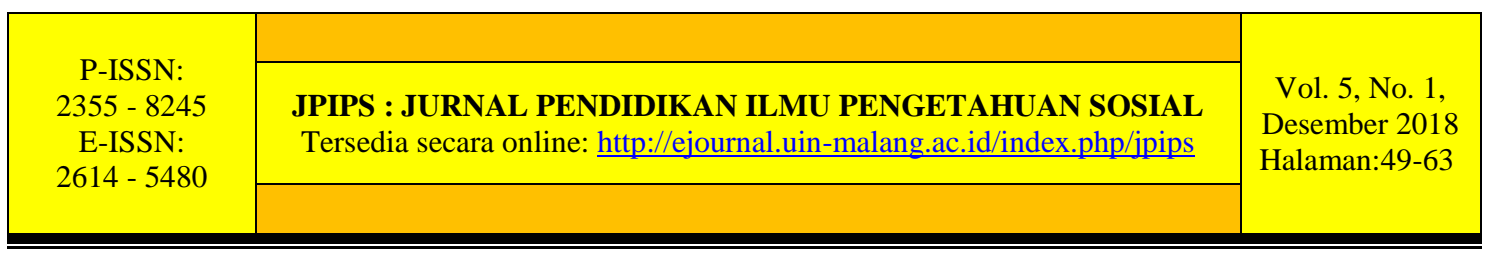

\title{
IMPLEMENTASI KEGIATAN EKSTRAKURIKULER KARYA TULIS ILMIAH UNTUK MENGEMBANGKAN BAKAT SISWA IPS DI MAN MODEL BOJONEGORO
}

\author{
Halimatus Sa'diyah \\ Universitas Islam Negeri Maulana Malik Ibrahim Malang \\ halimah@gmail.com
}

\begin{abstract}
Abstrak: Penelitian ini bertujuan untuk: (1) Mendeskripsikan program kegiatan ekstrakurikuler karya tulis ilmiah untuk mengembangkan bakat siswa IPS di MAN Model Bojonegoro, (2) Mendeskripsikan Implementasi kegiatan ekstrakurikuler karya tulis ilmiah untuk mengembangkan bakat siswa IPS di MAN Model Bojonegoro (3) Mengetahui hambatan dan solusi dalam kegiatan ekstrakurikuler karya tulis ilmiah untuk mengembangkan bakat siswa IPS di MAN Model Bojonegoro. Jenis penelitiannya adalah penelitian lapangan (field research) dan menggunakan pendekatan kualitatif bersifat deskriptif. Teknik pengumpulan data yang digunakan adalah observasi, wawancara, dokumentasi dan triangulasi. Data di analisis dengan cara pengumpulan data, reduksi, penyajian data dan penarikan kesimpulan. Hasil penelitian menunjukkan sebagai berikut: (1) Program kegiatan ekstrakurikuler karya tulis ilmiah disuguhkan agar siswa dapat mengembangkan bakat dibidang IPS dalam hal menulis dan penelitian. Kegiatan ekstrakurikuler karya tulis ilmiah sudah berjalan dengan baik dengan antusias siswa dalam mengikuti kegiatan (2) Implementasi kegiatan ekstrakurikuler karya tulis ilmiah siswa IPS meliputi: (a) Materi yaitu memilih materi pembelajaran sesuai dengan kondisi dan situasi yang melingkupi siswa (b) Metode yang digunakan antara lain metode ceramah, diskusi, tanya jawab dan penugasan. (c) Media, meliputi: media pandang dan pandang dengar seperti, laptop, LCD dan pengeras suara, (d) Evaluasi, meliputi: yaitu teknik evaluasi penugasan, praktik, serta membandingkan kualitas karya tulis ilmiah siswa dari tahun ke tahun. (3) Hambatan dalam kegiatan ekstrakurikuler karya tulis ilmiah untuk mengembangkan bakat siswa IPS di MAN Model Bojonegoro yaitu hambatan sarana dan prasarana serta keterbatasan waktu. Solusi dari pihak sekolah yaitu dengan penambahan sarana prasarana yang memadai, terutama akses internet dan tambahan bacaan serta penambahan alokasi waktu.
\end{abstract}

Kata Kunci: implementasi, ekstrakurikuler, karya tulis ilmiah, IPS

Abstract: This study aims to: (1) Describe the program of extracurricular activities of scientific papers to develop the talents of IPS students in MA del Bojonegoro, (2) Describe Implementation of extracurricular activities of scientific papers to develop the talents of IPS students in MAN Model Bojonegoro, (3) Knowing the obstacles and solutions in extracurricular activities of scientific papers to develop the talents of IPS students in MAN Model Bojonegoro. The type of research is field research (field research) and using a descriptive qualitative approach. Data collection techniques used are observation, interview, documentation and triangulation. Data is analyzed using the following scheme: data collection, reduction, data presentation and conclusion. The results of the research show as follows: (1) The program of extracurricular activity of 
scientific writing is a prominent activity, this activity is presented so that students can develop talents in the field of IPS in terms of writing and research, extracurricular activities of scientific papers have been running well with the enthusiasm of students in following the activities (2) Implementation of extracurricular activities of scientific papers the field of IPS include: (a) The material is choosing learning materials according to the conditions and circumstances surrounding the students $(b)$ The method used includes lecture, discussion, question and answer and assignment. (c) Media, include media of view and view of hearings such as, laptops, LCD and loudspeakers; (d) Evaluation include: the techniques of evaluation of assignments, practices, and comparing the quality of scientific papers students from year to year. (3) Obstacles in extracurricular activities of scientific papers to develop the talents of IPS students in MAN Model Bojonegoro namely the constraints of facilities and infrastructure and time constraints. The solution of the school is by the addition of adequate infrastructure, especially internet access and additional reading and addition of time allocation.

Keywords: implementation, extracurricular, activities of scientific writing, IPS.

\section{PENDAHULUAN}

Suatu bangsa dikatakan maju bukan hanya yang memiliki kekayaan yang melimpah atau pun yang memiliki peralatan yang sudah canggih. Akan tetapi dapat dilihat dari potensi sumber daya manusia yang dimilikinya, sehingga dapat mengelola sumber daya alam dengan baik. Serta dengan sumber daya manusia yang berkualitaslah yang dapat menciptakan peralatan yang canggih. Agar terciptanya sumber daya manusia yang berkualitas maka perlu adanya suatu proses yaitu dengan pendidikan, proses yang mana dapat menumbuhkan potensi-potensi yang dimiliki oleh manusia secara utuh. (Syukur, 2011). Karena pendidikan sebagai investasi sumber daya manusia dipandang sebagai variabel terpenting yang mempengaruhi tercapainya kesejahteraan umat manusia. Dengan pendidikan yang baik diharapkan kualitas sumber daya manusia juga menjadi lebih baik, yang pada akhirnya dapat meningkatkan kualitas hidup manusia itu sendiri (Wahidmurni, 2010). Sebagaimana firman Allah dalam Al-qur'an surat Al-Mujadalah ayat 11:

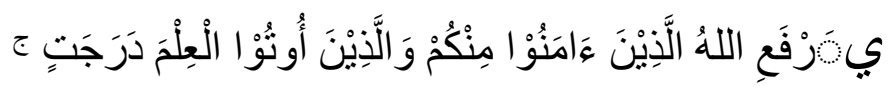

“...Allah akan meninggikan orang-orang yang beriman diantaramu dan orangorang yang diberi ilmu pengetahuan beberapa derajat... ”(Bahsri, 2009).

Pendidikan merupakan salah satu usaha pemerintah dalam meningkatkan kualitas sumber daya manusia demi tercapainya pembangunan diberbagai bidang, baik dibidang akademik maupun non akademik. Proses pembangunan pendidikan tidaklah cukup apabila hanya terfokus pada bidang akademik, akan tetapi juga harus difokuskan pada kegiatan non akademik, yang mana dapat menumbuh kembangkan bakat dan minat siswa. Sebagaimana tertuang dalam Undang-undang Republik Indonesia Nomor 20 Tahun 2003 tentang Sistem Pendidikan Nasional merupakan dasar hukum penyelenggaraan dan reformasi sistem pendidikan nasional. Undang-undang tersebut memuat visi, misi, fungsi dan tujuan pendidikan nasional, serta strategi pembangunan pendidikan nasional, untuk mewujudkan pendidikan yang bermutu, relevan dengan kebutuhan masyarakat, dan berdaya saing dalam kehidupan global. Lebih lanjut dalam pasal 3 Undang-undang Republik Indonesia No. 20 Tahun 2003 tentang Sistem Pendidikan Nasional yang berfungsi untuk mengembangkan kemampuan dan 
membentuk watak serta peradaban bangsa yang bermartabat dalam rangka mencerdaskan kehidupan bangsa, bertujuan untuk berkembangnya potensi peserta didik agar menjadi manusia yang beriman dan bertakwa kepada Tuhan yang Maha Esa, berakhlak mulia, sehat, berilmu, cakap, kreatif, mandiri, dan menjadi warga Negara yang demokratis serta bertanggung jawab (Bahsri, 2009).

Pendidikan merupakan kegiatan mengoptimalkan perkembangan potensi, kecakapan dan karakteristik pribadi peserta didik. Kegiatan pendidikan diarahkan kepada pencapaian tujuan-tujuan tertentu yang disebut tujuan pendidikan. Tujuan pendidikan minimal diarahkan kepada pencapaian empat sasaran, yaitu; (1) pengembangan segi-segi kepribadian, (2) pengembangan kemampuan kemasyarakatan,, (3) pengembangan kemampuan melanjutkan studi, dan (4) pengembangan kecakapan dan kesiapan untuk bekerja (Sukmadinata, 2013).

Sekolah sebagai tempat untuk mewujudkan dari tujuan pendidikan nasional seperti yang dituangkan dalam Undang-undang Republik Indonesia No. 20 Tahun 2003 tentang Sistem Pendidikan Nasional. Dengan adanya suatu lembaga pendidikan tersebut maka proses pembentukan watak dan pengembangan potensi peserta didik akan bisa terstruktur. Pendidikan di sekolah menyiapkan manusia yang intelek, pandai dan cerdas dalam menerapkan ilmu pengetahuan dan keahliannya serta memberikan situasi belajar kepada siswanya tempat di mana mereka dapat mengembangkan bakatnya melalui kegiatan non akademik atau ekstrakurikuler sekolah. Yang mana ekstrakurikuler tergolong dalam komponen pengembangan diri (An-Nahlawi, 1995).

Bayangkan sebuah sekolah di mana berbagai model pengajaran tidak hanya dirancang untuk mencapai ruang lingkup tujuan-tujuan kurikulum (belajar membaca; menghitung; memahami sistem matematika; memahami dunia sastra, sains, dan sosial; dan terlibat dalam pertunjukan seni dan atletik), tetapi juga dirancang untuk membantu para siswa meningkatkan kekuatan mereka sebagai pembelajar (to help student increase their power as learner). Saat mereka menguasai informasi dan keterampilan, hasil dari setiap pengalaman belajar bukan hanya soal isi/ pelajaran yang dapat mereka pelajari, tetapi juga meningkatnya kemampuan mereka untuk menyelesaikan tugas-tugas pembelajaran masa depan (Joyce, Weil \& Calhoun, 2011).

Ekstrakurikuler dalam pendidikan dimaksudkan sebagai jawaban atas tuntutan dari kebutuhan anak didik, membantu mereka yang kurang, memperkaya lingkungan belajar dan memberikan stimulasi kepada mereka agar lebih kreatif. Suatu kenyataan bahwa banyak kegiatan pendidikan yang tidak selalu dapat dilakukan dalam jam-jam sekolah yang terbatas itu, sehingga terbentuklah perkumpulan anak-anak diluar jam sekolah yang dianggap dapat menampung dan memenuhi kebutuhan serta minat mereka. Sebenarnya kurikulum tidak selalu membatasi anak didik dalam kelas saja, tetapi segala kegiatan pendidikan di luar kelas atau di luar jam sekolah yangs sering disebut sebagai kegiatan ekstrakurikuler. Ekstrakurikuler merupakan program pendidikan yang dilaksanakan di bawah tanggung jawab dan bimbingan sekolah (Anwar, 2015).

Ekstrakurikuler merupakan suatu kegiatan yang dilakukan oleh para siswa di luar jam pelajaran biasa untuk membantu pengembangan peserta didik sesuai dengan kebutuhan, potensi, bakat dan minat melalui kegiatan yang secara khusus diselenggarakan oleh pendidik yang memiliki kemampuan dan kewenangan di sekolah. Adapun kegiatan ekstrakurikuler yang dilaksanakan di sekolah terdapat beberapa jenis (Departemen Pendidikan dan Kebudayaan, 1995). Salah satunya adalah kegiatan karya tulis ilmiah. Istilah karya tulis ilmiah digunakan untuk menyebut sebuah tulisan yang 
disusun sesuai dengan kaidah-kaidah yang baku dan menggunakan metode ilmiah (Syarbini, 2010). Karya tulis ilmiah itu sangat penting bagi pelajar sebagai bentuk kegiatan berkomunikasi ilmiah secara tertulis.Dari para pelajar sangat diharapkan bermunculan berbagai pemikiran atau gagasan keilmuan yang dapat melengkapi khazanah perkembangan ilmu (Kusmana, 2010).

Ibu Hanik selaku pembimbing ekstrakurikuler karya tulis ilmiah di MAN Model Bojonegoro berpendapat bahwa, jumlah siswa yang mengikuti kegiatan ekstrakurikuler karya tulis ilmiah yang meraih prestasi baik ditingkat Kabupaten, Kota maupun ditingkat Provinsi mengalami peningkatan $10 \%$ hingga $15 \%$. Berdasarkan tabel di bawah ini:

Tabel 1 Daftar prestasi siswa ekstrakurikuler Karya Tulis Ilmiah

\begin{tabular}{cl}
\hline Tahun & \multicolumn{1}{c}{ Prestasi Siswa Karya Tulis Ilmiah } \\
\hline 2015 & $\begin{array}{l}\text { Juara III KIR tingkat kabupaten Bojonegoro dan juara IIKIR } \\
\text { kependudukan tingkat kabupaten Bojonegoro }\end{array}$ \\
2016 & $\begin{array}{l}\text { Juara III LKTI Kependudukan tingkat wilker Bojonegoro dan juara I } \\
\text { KIR bidang Sosial Budaya tingkat SMA/MAN se-Jawa Bali }\end{array}$ \\
2017 & Juara II Karya Tulis Ilmiah dan juara ILKTI Geografi se-Jawa Bali \\
\hline
\end{tabular}

Sumber: Ibu Hanik Fauziah selaku Pembina ekstrakurikuler KIR

Berdasarkan tabel 1 menunjukkan bahwa kegiatan ekstrakurikuler karya tulis imiah di MAN Model Bojonegoro pada tahun 2015dapatmeraih juaraIII dan II ditingkat Kabupaten. Seiring berjalannya waktu pada tahun 2016 kegiatan ekstrakurikuler karya tulis ilmiah MAN Model Bojonegoro dapat mempertahankan prestasinya dengan meraih juara III LKTI Kependudukan tingkat Wilayah Karesidenan Bojonegoro (WILKER) dan juara II KIR bidang Sosial Budaya tingkat SMA/MAN se-Jawa Bali. Di tahun 2017 kegiatan eskstrakurikuler karya tulis ilmiah MAN Model Bojonegoro dapat meningkatkan prestasi dengan meraih juara II dan juara I LKTI Geografi ditingkat provinsi se-Jawa Bali.

Sehubungan dengan hal tersebut MAN Model Bojonegoro merupakan salah satu sekolah yang memiliki perhatian terhadap masalah pengembangan diri (bakat) hal ini dibuktikan dalam melakukan upaya-upaya untuk mengembangkan program pengembangan bakat. Salah satu upayanya yakni dengan memberikan wadah bagi siswa suatu organisasi karya ilmiah remaja yang ditujukan bagi siswa yang gemar menulis karya ilmiah dan yang ingin mempelajari lebih dalam tentang karya tulis ilmiah sebagai pengembangan diri. Di samping itu, MAN Model Bojonegoro merupakan salah satu sekolah model dan berprestasi yang memiliki keterbukaan sangat baik terhadap pihak luar yang bertujuan untuk sebuah penelitian pendidikan. Siswa MAN Model Bojonegoro memiliki prestasi baik dalam menulis serta mempunyai antusiasme tinggi terhadap keterampilan menulis, selain itu sebelumnya juga sudah memenangkan beberapa perlombaan karya tulis, hal tersebut membuktikan bahwa sekolah tersebut memang berkompeten dalam hal karya tulis.Berangkat dari latar belakang di atas, penulis merasa tertarik untuk melakukan penelitian tentang implementasi kegiatan ekstrakurikuler karya tulis ilmiah untuk mengembangkan bakat siswa di MAN Model Bojonegoro.

\section{METODE}

Metode penelitian yang digunakan dalam penelitian ini adalah metode penelitian kualitatif dengan jenis penelitian lapangan. Dan pengumpulan data yang digunakan 
adalah observasi, wawancara dan dokumentasi. Penelitian kualitatif pada permulaannya banyak digunakan dalam bidang sosiologi, antropologi, dan kemudian memasuki bidang psikologi, pendidikan, bahasa dan cabang-cabang ilmu sosial lainnya. Penelitian kualitatif, dalam analisis datanya tidak menggunakan analisis statistik, tetapi lebih banyak secara naratif; sedangkan dalam penelitian kuantitatif sejak awal proposal dirumuskan, data yang akan dikumpyulkan hendaklah data kuantitatif atau yang dapat dikuantitatifkan. Sebaliknya, dalam penelitian kualitatif sejak awal ingin mengungkapkan data secara kualitatif dan disajikan secara naratif (Yusuf, 2017).

Penelitian ini dilakukan di MAN Model Bojonegoro yang berada di alamat Jalan Monginsidi No.160, Sukorejo, Kec. Bojonegoro, Kab. Bojonegoro, Jawa Timur dengan subjek penelitian adalah siswa MAN Model Bojonegoro. Data Dan Sumber Data yang dilakukan dalam penelitian ini peneliti akan berusaha mengumpulkan data dari beberapa sumber yang bersangkutan antara lain Kepala sekolah, guru Pembina, siswa di MAN Model Bojonegoro. Yang kemudian di kelompokkan lagi menjadi data primer (data yang diperoleh atau dikumpulkan dari lapangan oleh orang yang melakukan penelitian) dan data sekunder (data yang diperoleh atau dikumpulkan oleh orang yang melakukan penelitian dari sumber-sumber yang telah ada). KemudianTeknik pengumpulan data yang dilakukan dalam penelitian ini adalah mengunakan observasi dan wawancara.

Tabel 2 Tema Wawancara

\begin{tabular}{|c|c|c|}
\hline No. & Informan & Tema \\
\hline 1. & Guru Pembina KTI & $\begin{array}{l}\text { Program pengembangan kegiatan ekstrakurikuler karya tulis ilmiah } \\
\text { bidang IPS } \\
\text { Pelaksanaan kegiatan ekstrakurikuler karya tulis ilmiah bidang IPS } \\
\text { Evaluasi kegiatan ekstrakurikuler karya tulis ilmiah bidang IPS } \\
\text { Hambatan dan solusi pelaksanaan kegiatan ekstrakurikuler karya } \\
\text { tulis ilmiah bidang IPS }\end{array}$ \\
\hline 2. & Siswa & $\begin{array}{l}\text { Respon siswa terhadap adanya kegiatan ekstrakurikuler karya tulis } \\
\text { ilmiah }\end{array}$ \\
\hline 3. & Kepala Sekolah & $\begin{array}{l}\text { Program pengembangan kegiatan ekstrakurikuler karya tulis ilmiah } \\
\text { bidang IPS } \\
\text { Pelaksanaan kegiatan ekstrakurikuler karya tulis ilmiah bidang IPS } \\
\text { Evaluasi kegiatan ekstrakurikuler karya tulis ilmiah bidang IPS }\end{array}$ \\
\hline
\end{tabular}

\section{HASIL DAN PEMBAHASAN Hasil}

\section{Program Kegiatan Ekstrakurikuler Karya Tulis Ilmiah di MAN Model Bojonegoro Program kegiatan ekstrakurikuler karya tulis ilmiah di MAN Model Bojonegoro diterapkan sejak tahun 2004}

Latar belakang kegiatan Ekstrakurikuler Karya Tulis Ilmiah tersebut di antaranya adalah sebagai berikut:

a. Menciptakan peserta didik yang kreatif dan berprestasi di dunia IPTEK

b. Banyaknya lomba-lomba baik ditingkat kabupaten/kota, maupun tingkat provinsi

c. Mengenalkan siswanya tentang madrasah riset dan menghidupan majalah sekolah serta sebagai bentuk peran lembaga dalam mengembangkan potensi dan bakat peserta didik dalam menghadapi era globalisasi dan modernisasi yang terjadi saat ini.

d. Siswa diharapkan mampu membawa nama baik sekolah di tingkat kabupaten/kota, provinsi maupun di tingkat nasional.

e. Siswa diharapkan mampu memiliki jiwa ilmiah dan peka terhadap lingkungan serta memanfaatkan sebaik-baiknya 
Pelaksanaan kegiatan ini diawasi oleh kepala sekolah, waka kesiswaan, dan dikelola oleh guru Pembina. Kegiatan ekstrakurikuler karya tulis ilmiah dilaksanakan setiap hari senin selama satu jam, mulai pukul 15.00 - 16.00 WIB yang bertempat di Perpustakaan sekolah.

Kegiatan ekstrakurikuler karya tulis ilmiah di MAN Model Bojonegoro sudah cukup baik, terlihat dari antusias siswa-siswi dalam mengikuti kegitan ini dengan bersemangat dan mampu meraih juara tingkat Provinsi Jawa Timur dalam 3 tahun ini.

\section{Implementasi Kegiatan Ekstrakurikuler Karya Tulis Ilmiah untuk Mengembangkan Bakat Siswa IPS di MAN Model Bojonegoro}

Pelaksanaan kegiatan ekstrakurikuler karya tulis ilmiah materi dihimpun dari sejumlah makalah, artikel, serta jurnal. Materi yang diberikan fokus untuk mempersiapkan siswa menghadapi lomba, yaitu materi umumnya tentang sistimetika penulisan. Kemudian metode yang digunakan ketika pembinaan yaitu ceramah, diskusi, serta praktik. Guru pembina menyampaikan materi dengan metode ceramah yang disertai contoh-contoh karya ilmiah. Metode diskusi dipilih agar siswa terlatih bekerja secara team dalam menyelesaikan suatu permasalahan, kemudian dengan praktik agar guru dapat mengukur pemahaman siswa mengenai materi yang telah disampaikan. Dalam mengembangkan bakat siswa yang harus dilakukan adalah dengan pembinaan secara terus menerus, memotivasi siswa, memberikan tantangan untuk dianalisis siswa serta melatih siswa untuk menampilkan hasil penelitian dihadapan ibu bapak guru dengan tujuan melatih mental siswa.

Media dalam kegiatan ini meliputi laptop beserta perangkat layar LCD guna menampilkan slide-slide materi yang dilanjutkan dengan penjelasan Pembina. Evaluasi yang digunakan oleh guru Pembina dalam pelaksanaan pembinaan kegiatan ekstrakurikuler karya tulis ilmiah siswa MAN Model Bojonegoro menggunakan penilaian proses dan penilaian hasil

\section{Hambatan dan Solusi Kegiatan Ekstrakurikuler Karya Tulis Ilmiah untuk Mengembangkan Bakat Siswa IPS di MAN Model Bojonegoro}

Hambatan dalam kegiatan ekstrakurikuler karya tulis ilmiah adalah dalam segi sarana prasarana yang digunakan dalam kegiatan ekstrakurikuler karya tulis ilmiah kurang memadai. Hambatan lain yang dihadapi oleh MAN Model Bojonegoro yaitu keterbatasan waktu yang kadang berbenturan dengan jam pelajaran lain sehingga siswa banyak yang izin untuk tidak mengikuti pembelajaran di kelas.

Solusi untuk mengatasi hambatan mengenai sarana prasarana, sekolah sedang berusaha untuk melengkapi dan akan dilaksanakan pada pelaksanaan ekstrakurikuler karya tulis ilmiah pada periode berikutnya. Sedangkan dalam hal alokasi waktu, maka sekolah mempunyai solusi untuk menambah jam pembinaan karya tulis ilmiah yaitu dua hari dalam satu minggu.

\section{Pembahasan}

Program Kegiatan Ekstrakurikuler Karya Tulis Ilmiah untuk Mengembangkan Bakat Siswa IPS di MAN Model Bojonegoro

Jumlah siswa yang ada di MAN Model Bojonegoro yaitu siswa yang terbagi ke dalam beberapa kelas. Kelas X, XI, XII yang masing-masing terdapat kelas IPA, IPS dan Bahasa. Adapun persentase jumlah siswa yang mengikuti ekstrakurikuler karya tulis ilmiah di MAN Model Bojonegoro jumlah siswa seluruhnya 753 siswa, untuk KIR 
$35 \%$, olimpiade $25 \%$, olahraga dan seni $30 \%$ serta $10 \%$ tidak mengikuti. Sedangkan pada ekstrakurikuler pramuka semua siswa diwajibkan mengikuti kecuali kelas XII.

Table 3 Data Persentase Jumlah Siswa yang Mengikuti Kegiatan Ekstrakurikuler

\begin{tabular}{llcc}
\hline No. & \multicolumn{1}{c}{ Ekstrakurikuler } & $(\boldsymbol{\%})$ & Jumlah \\
& & $35 \%$ & Siswa \\
\hline 1. & KIR & $25 \%$ & 264 \\
2. & Olimpiade & $30 \%$ & 188 \\
3. & Olahraga dan Seni dll & $10 \%$ & 226 \\
4. & Tidak Mengikuti & 75 \\
\hline
\end{tabular}

Program kegiatan karya tulis ilmiah merupakan salah satu kegiatan ekstrakurikuler yang sifatnya terbuka bagi para siswa yang ingin mengembangkan kreativitas, ilmu pengetahuan,dan teknologi pada masa kini maupun pada masa yang akan datang.Berdasarkan hasil wawancara yang dilakukan dilapangan dengan ibu HanikFauziyah, M.Pd selaku Pembina Ekstrakurikuler Karya Tulis Ilmiah, beliau menjelaskan bahwa:

"Ekstrakurikuler karya tulis ilmiah merupakan ekstrakurikuler yang memiliki tujuan yang jelas, mendidik kaum muda untuk berfikir ilmiah dalam mengembangkan ilmu pengetahuan dan teknologi sesuai kaidah yang berlaku"

Dalam kegiatan belajar mengajar dipendidikan formal seperti pada tingkat SMA/MAN tentunya tidak lepas dari kegiatan ekstrakurikuler, karena kegiatan ekstrakurikuler ada untuk mengembangkan potensi yang dimiliki oleh peserta didik, seperti yang ada di MAN Model Bojonegoro terdapat banyak pilihan kegiatan ekstrakurikuler yang dapat diminati oleh peserta didik untuk mengembangkan potensi atau bakat yang dimilikinya. Salah satunya yaitu program kegiatan ekstrakurikuler karya tulis ilmiah bidang IPS, di mana kegiatan ini awal diterapkan pada tahun 2004 untuk mengenalkan anak-anak tentang menulis dan kegiatan penelitian.

Hal ini berdasarkan pada hasil wawancara dengan ibu Hanik Fauziyah, M.Pd, sebagai berikut:

"program kegiatan ekstrakurikuler ini dimulai pada tahun 2004 mbak, awalnya mereka (siswa-siswi) masih asal-asalan ketika menulis sampai pada akhirnya ada perubahan, nah yang melatar belakangi adanya kegiatan ekstrakurikuler karya tulis ilmiah ini adalah menyalurkan rasa ingin tahu siswa-siswi tentang menulis, terus imajinasi mereka, ide kreatif mereka kemudian dituangkan dalam bentuk tulisan salah satunya yaitu bidang IPS, yang kedua karena banyaknya lombalomba, terutama lomba karya tulis ilmiah tingkat kota, tingkat provinsi maupun tingkat nasional, sehingga anak-anak juga semangat dalam belajar karena akan diikutkan dalam kompetisi".

Pendapat tersebut juga ditambahkan dari hasil wawancara dengan Kepala Sekolah pak Drs. Saifuddin Yulianto, S.Ag, M.PdI sebagai berikut:

"adanya pelaksanaan kegiatan ekstrakurikuler karya tulis ilmiah dalam mengembangkan bakat siswa diarahkan untuk mempersiapkan kader penerus bangsa dan pembangunan nasional mbak, yaitu dengan memberikan bekal keterampilan, daya kreasi yang berbudi pekerti luhur." 
Pelaksanaan kegiatan ekstrakurikuler di MAN Model Bojonegoro diawasi oleh kepala sekolah, waka kesiswaan dan dikelola oleh pembina ekstrakurikuler karya tulis ilmiah, sebagaimana hasil wawancara dengan kepala sekolah bapak Drs. H. Saifuddin Yulianto, S.Ag, M.PdI sebagai berikut:

"personil yang terlibat dalam pengawasan pelaksanaan kegiatan ini diantaranya kepala sekolah, waka kesiswaan dan Pembina ekstrakurikuler karya tulis ilmiah mbak."

Kegiatan ekstrakurikuler karya tulis ilmiah dilaksanakan seminggu sekali pada hari senin, berlangsung selama 1 jam yaitu pukul $15.00-16.00$ WIB yang bertempat di Perpustakaan sekolah. Dalam kegiatan ini diikuti sebagian siswa kelas XIPS sampai kelas XII IPS. Dalam kegiatan ini dilakukan pembimbingan secara intensif ketika akan menghadapi event.Sebagaimana hasil wawancara dengan ibu Hanik Fauziyah, M.Pd sebagai berikut:

"untuk pelaksanaan kegiatan ini ketika tidak ada lomba maka seminggu sekali kita bertatap muka yaitu pada hari senin setiap pulang sekolah, ketika akan menghadapi lomba minimal dua kali bertatap muka dalam seminggu sesuai kebutuhan. Untuk tempat pembimbingan kita gunakan perpustakaan sebagai bascame anak karya tulis ilmiah tetapi kadang juga di tempat lain yang menurut kita nyaman untuk dipakai”.

Hal ini juga ditambahkan dari hasil wawancara dengan siswa yang bernama Fira Kelas XI, sebagai berikut:

"Kegiatan ekstrakurikuler karya tulis ilmiah ini dilaksanakan seminggu sekali pada awalnya mbak, kemudian dilakukan pembimbingan setiap hari jika ada kompetisi atau event karya tulis ilmiah karena dalam penelitian tidak cukup jika hanya satu kali dalam seminggu, apalagi jika akan menghadapi lomba"

Pendapat tersebut juga ditambahkan oleh siswa yang bernama Aulia kelas XI sebagai berikut:

"Biasanya pembinaan ekstrakurikuler karya tulis ilmiah berlangsung selama 1 jam, mulai dari jam 15.00-16.00 WIB, tetapi ketika akan menghadapi lomba ditambah jam pembinaannya mbak".

Berdasarkan observasi lapangan yang penulis lakukan di MAN Model Bojonegoro terlihat bahwa antusias anak-anak sangat baik padakegiatan ekstrakurikuler dalam menunjang prestasi belajar siswa non akademik terutama dalam kegiatan ekstrakurikuler karya tulis ilmiah, terbukti anak-anak sangat bersemangat untuk mengikuti kegiatan ini dan hasilnya sangat memuaskan yang mampu meraih Juara 1 tingkat Provinsi Jawa Timur dalam Lomba Karya Tulis Ilmiah Kependudukan yang diselenggarakan oleh BkkbN pada program KKBPK Tingkat Provinsi Jawa Timur tahun 2018. M.Pd.

Sebagaimana hasil wawancara yang dilakukan dengan Ibu Hanik Fauziyah, 
“Anak-anak sangat bersemangat dalam mengikuti kegiatan ekstrakurikuler karya tulis ilmiah, terutama anak-anak yang pernah meraih juara lomba karya tulis ilmiah yang kemarin diadakan di Surabaya.Dia sangat bersemangat sampaisampai belum selesai melakukan penelitian dia sudah mempunyai ide baru untuk diteliti mbak".

Pernyataan diatas mendapat tambahan dari Kepala Sekolah Bapak M. Saifuddin Yulianto, S.Ag, M.Pd.I sebagai berikut:

"kondisi kegiatan yang terlihat sangat baik, terlihat dari antusias anak-anak yang mengikuti kegiatan tersebut dengan bersemangat apalagi ketika mendekati lomba, siswa sangat berpartisipasi untuk mengikuti lomba yang akan diadakan."

Kegiatan ekstrakurikuler karya tulis ilmiah sangatlah bermanfaat bagi siswasiswi karena mereka bisa menambah wawasan, pengetahuan, teman baru, serta inspirasi untuk selalu berkarya karena seringnya mengikuti lomba karya ilmiah baik di tingkat kabupaten/kota serta tingkat provinsi. Hal tersebut diungkapkan siswa yang bernama Tina kelas XI Sebagai berikut:

"semenjak saya mengikuti kegiatan ekstrakurikuler karya tulis ilmiah saya terinspirasi untuk selalu berkarya terutama dibidang penulisan karya ilmiah IPS dan ketika saya mengikuti lomba melihat pesaing saya lebih memiliki ide yang mungkin saya belum bisa membuatnya, saya semakin termotivasi untuk lebih giat dalam belajar mbak"

Pendapat tersebut juga dikemukakan oleh ibu Hanik Fauziyah, M.Pd sebagai berikut:

"ya untuk mengembangkan bakat siswa mbak terlebih anak IPS, soalnya anak IPS kan cenderung banyak berimajinasi tapi yang termasuk dalam konsep pemikiran ilmiah, nah itu bisa dikembangkan melalui kegiatan ini, kita mewadahi kreatifitas mereka dengan ekstrakurikuler karya ilmiah ini."

Hal itu juga ditambahkan oleh Kepala Sekolah bapak M. Saifuddin Yulianto, S.Ag, M.PdI sebagai berikut:

"manfaat dari kegiatan ekstrakurikuler ini yaitu dikembangkannya madarasah riset atau penelitian, kemudian akan dituangkan dalam bentuk buku yang itu akan menjadi salah satu produk dari kegiatan ekstrakurikuler karya tulis ilmiah itu sendiri. Yang kedua yaitu menghidupkan majalah siswa yang telah lama tidak berfungsi mbak, selain itu akan menambah pengetahuan dan pengalaman bagi siswa juga bagi guru itu sendiri."

Kemudian peneliti juga bertanya terkait produk yang dimaksud oleh kepala sekolah sebagai hasil dari kegiatan ekstrakurikuler karya tulis ilmiah, pak Saifuddin menjawab: 
"kalau produk yang dihasilkan yaitu karya siswa yang dibukukan seperti Didaktika Religia, Antologi Metode Pembelajaran, Antologi Scientific Paper, selain itu siswa juga sering meraih juara baik ditingkat kota/kabupaten maupun tingkat Provinsi”.

Dari penjelasan pak Saifuddin tersebut jelaslah bahwa di MAN Model Bojonegoro sudah mempunyai produk tersendiri yaitu karya ilmiah yang sudah dibukukan dan siswa dapat menjuarai berbagai lomba baik di tingkat kota/kabupaten maupun ditingkat provinsi.

Fungsi kegiatan ekstrakurikuler karya tulis ilmiah untuk mengembangkan bakat siswa IPS sebagaimana yang diungkapkan kepala sekolah bapak Drs. H. Saifuddin Yulianto, S.Ag, M.PdI sebagai berikut:

“jadi fungsi keberadaan kegiatan ekstrakurikuler karya tulis ilmiah itu sangat penting untuk mengembangkan bakat siswa baik ketika masih di bangku sekolah maupun untuk melanjutkan kehidupan setelah pendidikan di MAN karena kemampuan karya tulis ilmiah tersebut mengajarkan banyak tentang life skill yaitu keterampilan-keterampilan untuk hidup. Dalam hal ini siswa mempunyai kemampuan dalam bidang menulis ilmiah yang memiliki dampak jangka panjang.Makanya kalau ditanya mengenai kemanfaatan pandangan tentang karya tulis ilmiah yaitu sangat urgent atau penting karena sebagai bekal life skill di masa mendatang".

Jadi pandangan kepala sekolah di MAN Model Bojonegoro terhadap kegiatan ekstrakurikuler karya tulis ilmiah sendiri adalah bahwa fungsinya sangat penting karena sebagai bekal life skill di masa mendatang.Life skill yaitu keterampilan-keterampilan untuk hidup.

\section{Implementasi Kegiatan Ekstrakurikuler Karya Tulis Ilmiah untuk Mengembangkan Bakat Siswa IPS di MAN Model Bojonegoro}

Implementasi Kegiatan Ekstrakurikuler Karya Tulis Ilmiah di MAN Model Bojonegoro memiliki pengaruh yang penting dalam mengembangkan bakat siswa khususnya di jurusan IPS baik dimasa sekarang maupun di masa yang akan datang. Dalam hal ini guru pembina memiliki peranan penting dalam proses pelaksanaankegiatan ekstrakurikuler karya tulis ilmiah kepada siswanya.

Untuk mengetahui proses pelaksanaan kegiatan ekstrakurikuler karya tulis ilmiah di MAN Model Bojonegoro, maka peneliti juga melakukan wawancara dengan guru Pembimbing dan juga melakukan pengamatan saat pelaksanaan yaitu di ruang perpustakaan. Selanjutnya peneliti bertanya tentang pelaksanaan kegiatan karya tulis ilmiah untuk mengembangkan bakat siswa IPS di MAN Model Bojonegoro yang terkait dengan komponen pembelajaran, yaitu materi pembelajaran, metode pembelajaran, media pembelajaran, dan evaluasi pembelajaran. Adapun data yang disajikan, diperoleh melalui pengamatan, dokumentasi serta wawancara dengan guru Pembina KTI dan siswa.Berikut adalah uraian sejumlah materi, metode, media, dan pelaksanaan evaluasi yang digunakan guru pembimbing dalam pelaksanaan kegiatan ekstrakurikuler karya tulis ilmiah.

Berdasarkan hasil dokumentasi materi yang digunakan dalam pembinaan kegiatan ekstrakurikuler karya tulis ilmiah siswa MAN Model Bojonegoro dihimpun 
dari sejumlah makalah, artikel, dan jurnal yang diselaraskan dengan tujuan pembelajaran karya tulis ilmiah. Akan tetapi, lebih difokuskan pada penulisan, cara mencari referensi yang baik untuk mendukung penelitian serta mempersiapkan siswa untuk mengikuti lomba.Dalam kegiatan ini lebih banyak praktik dan sedikit teori yang disampaikan.Guru pembina melakukan beberapa langkah pembelajaran dalam menyampaikan materi untuk membantu pemahaman siswa. Sebagaimana hasil wawancara dengan Pembina KTI ibu Hanik Fauziyah, .M.Pd sebagai berikut:

"tujuan dalam pembinaan karya tulis ilmiah adalah mencetak anak-anak agar mampu mengkaji sebuah masalah dengan sudut pandang yang luas mbak, dan setelah mengkaji masalah tersebut dengan baik mampu memberikan solusi dari masalah yang ada dan mampu menuliskan dalam bentuk laporan yang sistematis.Untuk pemberian teori-teori atau dasar-dasar terkait karya tulis ilmiah itu sudah diberikan oleh guru bahasa Indonesia, jadi saya tinggal melanjutkan dan mengingatkan kembali atau kalau perlu ya saya tambahkan.Selain itu materi yang saya berikan ke siswa itu sesuai kebutuhan mbak. Misalnya mengenai penulisan dan cara mencari referensi yang baik untuk mendukung penelitian serta mempersiapkan siswa untuk mengikuti lomba. Jadi saya tidak mau kalo disuruh menerangkan per bab gitu, sekarang menerangkan bab 1,2,3 dan seterusnya. Maka nanti akan lama mbak.Jadi lebih banyak praktik."

Pendapat tersebut juga ditambahkan oleh peserta didik yang bernama Fira kelas XI sebagai berikut:

"bu Hanik kalau menyampaikan materi itu menyesuaikan lomba yang akan diikuti mbak. Selain itu juga tata cara penulisan serta referensi yang digunakan. Kalau materi yang disampaikan selain untuk mengikuti lomba, biasanya diberikan gambaran terlebih dahulu untuk memancing ide kreatif siswa.Yang akhirnya dijadikan obyek kajian kita atau bisa dikatakan selalu memberikan tantangan baru untuk dianalisis."

Dari data tersebut bisa disimpulkan bahwa materi yang disampaikan lebih pada persiapan menghadapi lomba seperti mengajarkan penulisan karya ilmiah yang benar serta mengajarkan prosedur penelitian.Selain itu juga guru selalu memberikan tantangan kepada siswa untuk dianalisis.

Metode dalam suatu pembelajaran sangatlah penting karena dengan adanya suatu metode memudahkan guru dalam menyampaikan ilmu kepada siswanya.Metode yang digunakan oleh guru Pembimbing dalam kegiatan ekstrakurikuler karya tulis ilmiah siswa IPS MAN Model Bojonegoro antara lain metode ceramah, diskusi, tanya jawab dan penugasan.

Berdasarkan hasil pengamatan selama pelaksanaan pembinaan kegiatan ekstrakurikuler karya tulis ilmiah, metode yang terlihat dominan digunakan oleh Pembina secara keseluruhan adalah metode diskusi, tanya jawab dan penugasan. Sama halnya yang telah dikatakan oleh ibu Hanik Fauziyah sebagai berikut:

“jadi di sini ekstrakurikuler karya tulis ilmiah tidak sekedar menyampaikan teori. Untuk mengawali pembelajaran saya kasih gambaran tentang kegiatan yang akan dilakukan, kemudian muncullah beberapa pertanyaan dari siswa yang 
kemudian akan didiskusikan. Setelah itu langsung penugasan. Sedangkan agar bakat karya tulis ilmiah siswa berkembang siswa selalu diikutkan lomba, dengan adanya pembimbingan secara terus menerus baik sebelum maupun disaat akanmengadapi lomba, melatih siswa untuk menampilkan hasil penelitian dihadapan siswa maupun ibu bapak guru. Menurut saya metode yang paling tepat adalah ceramah, diskusi serta langsung praktik atau penugasan”.

Hal tersebut sesuai dengan pernyataan siswa yang bernama Tina kelas XI sebagai berikut:

"dalam pelaksanaan kegiatan ekstrakurikuler karya tulis ilmiah biasanya bu Hanik menjelaskan terlebih dahulu mengenai poin-poin topik yang akan dibahas, kemudian ada sesi tanya jawab sebentar dan langsung praktik. Tetapi untuk tanya jawabnya lebih banyak pada waktu praktik atau bisa dikatakan konsultasi ke beliau."

Berdasarkan pengamatan, wawancara dan dokumentasi media yang digunakan guru dalam kegiatan ekstrakurikuler karya tulis ilmiah siswa IPS MAN Model Bojonegoro yaitu laptop beserta perangkat layar LCD. Media berupa LCD untuk menampilkan slide-slide materi yang dilanjutkan dengan tanya jawab serta penjelasan Pembina. Sebagaimana wawancara dengan Ibu Hanik Fauziyah, M.Pd sebagai berikut:

"untuk media kami memanfaatkan leptop beserta perangkat LCD Proyektor yang ada di perpustakaan mbak, itu untuk menunjang pemahaman siswa terhadap materi yang saya jelaskan, ya paling nggak ada gambaran buat bekal pengetahuan siswa."

Pendapat tersebut juga ditambahkan oleh siswa yang bernama Aulia kelas XI sebagai berikut:

"media yang digunakan saat pembinaan biasanya hanya memakai leptop sama LCD Proyektor mbak. Biasanya Pembina menampilkan slide-slide gitu terus dijelaskan setelah itu ada sesi Tanya jawab.Biasanya juga dilihatkan video eksperimen-eksperimen yang bisa memotivasi kita juga dan buat pengetahuan kita."

Evaluasi yang dilakukan guru dalam kegiatan ekstrakurikuler karya tulis ilmiah siswa IPS MAN Model Bojonegoro menggunakan penilaian proses dan hasil. Penilaian proses meliputi kehadiran siswa dalam kegiatan ekstrakurikuler KTI, antusias siswa, kemampuan bekerjasama dalam kelompok. Sedangkan, penilaian hasil meliputiprestasi siswa dalam lomba KTI, serta membandingkan kualitas karya ilmiah siswa dari tahun ke tahun. Sebagaimana hasil wawancara dengan Pembina KTI ibu Hanik Fauziyah, M.Pd sebagai berikut:

"evaluasinya secara pengamatan meliputi dua hal mbak, yang pertama yaitu dengan penilaian proses yang kedua dengan penilaian hasil. Yang mana jika penilaian proses meliputi kehadiran siswa dan keaktifan siswa pada waktu mereka mengikuti pembinaan. Kemudian untuk yang penilaian hasil meliputi 
pemahaman siswa terhadap materi, karya siswa dan prestasinya juga.Nah, semua itu kami jadikan pedoman untuk evaluasi. Dan yang paling mudah itu mengamati hasil mereka kan nanti nilainya berupa uraian deskriptif bukan angka. Ternyata dari nilai yang saya sampaikan ke mereka juga memberi semangat kepada mereka untuk terus belajar, dan kami juga memberi motivasi kepada mereka bahwa kegiatan ini tidak hanya berdiri di sini tetapi juga berguna nantinya misal untuk kuliah ataupun kerja."

Hasil evaluasi digunakan untuk perbaikan dan pengembangan kegiatan yang akan dilakukan selanjutnya. Untuk kegiatan ekstrakurikuler karya tulis ilmiah tindak lanjutnya yaitu dengan diikutkan lomba, itu salah satu cara sekolah mengetahui sejauhmana kemampuannya. Sebagaimana yang diungkapkan Pembina kegiatan ekstrakurikuler karya tulis ilmiah ibu Hanik Fauziyah, M.Pd:

"hasil evaluasi digunakan untuk perbaikan kegiatan yang akan dilakukan selanjutnya. Untuk ekstrakurikuler karya tulis ilmiah tindak lanjutnya diikutkan lomba mbak, itu salah satu cara mengetahui sejauhmana kemampuan kita."

Tindak lanjut dari hasil evaluasi adalah untuk memperbaiki pelaksanaan kegiatan ekstrakurikuler yang akan dilaksanakan pada periode berikutnya, jadi apabila ada permasalahan langsung diselesaikan. Sebagaimana yang diungkapkan bu Hanik Fauziyah, M.Pd:

“jika ada masalah ya kita selesaikan, misalnya jika prestasi dari anak karya ilmiah menurun yang tadinya juara I terus besok jadi juara II itu kita cari akar permasalahannya, kekurangannya apa dan nanti untuk pengembangan pelaksanaan yang akan datang. Kemarin itu pernah merosot gara-gara tema yang dipakai oleh siswa kami itu kurang terkini mbak, jadi tergeser satu point oleh siswa lain".

Berdasarkan uraian di atas dapat diketahui bahwa MAN Model Bojonegoro menggunakan hasil evaluasi untuk perbaikan pelaksanaan kegiatan ekstrakurikuler karya tulis ilmiah pada periode berikutnya. Perbaikan dilakukan dengan cara menyelesaikan permasalahan yang dihadapi dalam pelaksanaan kegiatan ekstrakurikuler karya tulis ilmiah pada periode ini supaya pelaksanaan berikutnya lebih baik.

\section{Hambatan dan Solusi Kegiatan Ekstrakurikuler Karya Tulis Ilmiah untuk Mengembangkan Bakat Siswa IPS di MAN Model Bojonegoro}

Proses mengimplementasikan kegiatan ekstrakurikuler karya tulis ilmiah untuk mengembangkan bakat siswa IPS, bu Hanik Fauziyah selaku Pembina menemukan beberapa hambatan ketika melakukan pembinaan,

"untuk hambatan itu sendiri dalam segi sarana dan prasarana, di sekolah ini masih kekurangan bahan pendukung dalam pembuatan karya tulis ilmiah mbak, misalnya referensi buku kurang banyak dan akses internet yang loading terus sehingga sebagai gantinya kita pergi ke Perpus kota mbak" 
Beberapa hal yang menjadi kendala atau hambatan dalam segi sarana dan prasarana, ibu Hanik Fauziyah menjelaskan bahwa di MAN ModelBojonegoro masih kurangnya fasilitas untuk mendukung proses pembinaan karya tulis ilmiah, misalnya kurangnya referensi buku baik yang bersifat manual ataupun elektronik, dan akses internet yang kurang support, sehingga dapat memperlambat proses pembinaan.

Dalam segi waktu pelaksanaan pembinaan karya tulis ilmiah yang dilaksanakan seusai jam sekolah sangatlah cepat, apalagi ketika akan menghadapi lomba maka benarbenar membutuhkan banyak waktu, sehingga pembinaan kegiatan ekstakurikuler kadang dilakukan saat mata pelajaran berlangsung guna penambahan waktu pembinaan ekstrakurikuler karya ilmiah dan dampaknya siswa menjadi sering izin pada saat jam pelajaran. Hal itu diutarakan oleh bu Hanik Fauziyah, M.Pd sebagai berikut:

"kita melaksanaan pembinaan ekstrakurikuler ini ketika jam pulang sekolah mbak, di mana sisa waktu tinggal sedikit. Jadi waktu merupakan kendala yang cukup serius ya mbak.Selain itu pada saat kita akan menghadapi lomba malah akan semakin membutuhkan waktu yang banyak, kadang anak-anak juga keluar saat mata pelajaran lain guna mengikuti pembinaan untuk lomba karya tulis ilmiah. Dan tak jarang nilai mereka jelek pada mata pelajaran yang ditinggalnya."

Peneliti juga menanyakan tentang solusi yang digunakan oleh ibu Hanik Fauziyah dalam menanggapi hambatan tersebut sehingga terwujudnya harapan dari kegiatan yang dilakukan, seperti halnya dengan hambatan yang ada dalam mengimplementasikan kegiatan ekstrakurikuler karya tulis ilmiah untuk mengembangkan bakat siswa IPS di MAN Model Bojonegoro. Dari beberapa hal di atas terdapat keterangan dan hasil wawancara sebagai berikut:

"kami di sini sebagai Pembina kegiatan ekstrakurikuler tidak jemu-jemunya, selalu memberikan motivasi kepada siswa agar tetap semangat dalam berkarya.

Kalau masalah sarana prasarana yang masih kurang, saya mensiasati untuk mengajak anak-anak ke Perpustakaan Kota mbak".

Untuk mensiasati sarana prasarana yang kurang, ibu Hanik Fauziyah mengajak siswanya untuk ke Perpustakaan Kota karena dirasa lebih banyak referensi yang dapat dimanfaatkan, selain itu untuk searching juga nyaman.

Dalam segi alokasi waktu pelaksanaan kegiatan ekstrakurikuler karya tulis ilmiah siswa IPS yang dilakukan pada jam pulang sekolah dan dirasa sangat singkat yang itu membuat siswa kewalahan, apalagi ketika mendekati lomba seringnya siswa keluar kelas pada saat jam pelajaran demi mengikuti pembinaan karya ilmiah yang berdampak pada nilai pelajaran mereka. Sehingga pihak sekolah memberi waktu lebih banyak lagi untuk kegiatan ekstrakurikuler karya tulis ilmiah, yang biasanya seminggu sekali menjadi dua kali dalam seminggu agar siswa bisa lebih berkonsentrasi dan fokus ketika akan mengikuti lomba serta tidak mengganggu pembelajaran di kelas.

\section{KESIMPULAN}

Berdasarkan data dan analisa yang telah dikemukakan, kesimpulan yang dapat diambil dari Implementasi Kegiatan Ekstrakurikuler Karya Tulis Ilmiah untuk Mengembangkan Bakat Siswa IPS di MAN Model Bojonegoro adalah sebagai berikut: 
1. Program kegiatan ekstrakurikuler karya tulis ilmiah di MAN Model Bojonegoro disuguhkan untuk mengembangkan bakat dan kreatifitas siswa IPS di MAN Model Bojonegoro dalam hal menulis dan penelitian. Kegiatan ini sudah cukup baik dibuktikan dengan antusias siswa dalam mengikuti kegiatan.

2. Pelaksanaan kegiatan ekstrakurikuler karya tulis ilmiah siswa IPS di MAN Model Bojonegoro ini ditinjau dari komponen pembelajaran, yaitu yang pertama melalui materi pembelajaran, metode pembelajaran, media pembelajaran, dan evaluasi pembelajaran.Sedangkan cara mengembangkan bakat yaitu dengan mempunyai keberanian, latihan rutin, memahami hambatan dan mengatasinya serta paham bahwa setiap orang pasti mempunyai bakat.

3. Hambatan yang dihadapi dalam implementasi kegiatan ekstrakurikuler karya tulis ilmiah di MAN Model Bojonegoro

a. Kurangnya sarana prasarana untuk menunjang kegiatan tersebut sehingga menghambat pelaksanaan kegiatan ekstrakurikuler.

b. Kurangnya alokasi waktu dalam pelaksanaan kegiatan ekstrakurikuler.

Solusi yang diberikan oleh sekolah untuk mengatasi hambatan pelaksanaan kegiatan ekstrakurikuler karya tulis ilmiah di MAN Model Bojonegoro adalah dengan melengkapi sarana prasarana yang masih kurang, sehingga memperlancar pelaksanaan kegiatan ekstrakurikuler tersebut serta dengan melakukan penambahan alokasi waktu.

\section{DAFTAR PUSTAKA}

An-Nahlawi, Abdurrahman. (1995). Pendidikan Islam Di Rumah, Sekolah Dan Masyarakat. Jakarta: Gema Insani Press.

Anwar, Sudirman. (2015). Management of Student Development (Perspektif Al-Qur'an \& As-Sunnah). Riau : Yayasan Indragiri.

Bashri, Muh. Mu'inudinnillah. (2009). Al-Qur'an dan Terjemahnya. Jakarta: Indiva.

Departemen Pendidikan dan Kebudayaan. (1995). Petunjuk Teknis Kegiatan Ekstrakurikuler. Jawa Barat; Departemen Pendidikan dan kebudayaan.

Joiyce, Bruce, Marsha Weil \& Emily Calhoun. (2011). Models of Teaching. Yogyakarta : Pustaka Pelajar

Kusmana, Suherli. (2010). Merancang Karya Tulis Ilmiah. Bandung: Rosdakarya.

Sukmadinata, Nana Syaodih. (2013). Metode Penelitian Pendidikan. Bandung : Remaja Rosdakarya.

Syarbini, Amirullah. (2011). Menulis Karya Tulis Ilmiah itu Mudah. Bandung: Fajar Media.

Syukur, Fatah . (2011). Manajemen Pendidikan Berbasis pada Madrasah. Semarang: Pustaka Rizki Putra.

Wahidmurni. (2010). Pengembangan Kurikulum IPS \& Ekonomi di Sekolah/Madrasah. Malang: UIN Maliki Press.

Yusuf, A. Muri. (2017). Metode Penelitian : Kuantitatif, Kualitatif, dan Penelitian Gabungan. Jakarta : Prenadamedia. 